\title{
How Green Was My Screen?
}

\author{
By Andrew R. J. Yeaman, Editor
}

\section{Scenario}

$C$ hris sat in the library media center at Central Middle School and was evaluating resources for teaching environmental problems. The materials examined covered topics such as fossil fuels, nuclear fuels, alternative energy sources, recycling, air pollution, and green house effect global warming. A bibliography reviewed population growth in relation to the history of agriculture, transportation, medicine, industrialization, schooling, and universal literacy but Chris stopped reading due to a flash of insight.

Pat, the librarian, was glad to assist with Chris' inquiry: "What are the environmental effects of educational technology?"

The search for answers proved fruitful but the results were startling. For instance, they learned how the numbers of computers in schools had increased.

Pat served on the district technology committee and suggested they work together to prepare a short report. When their presentation came up on the agenda, Chris spoke:

We should be aware of the ecological dilemmas we face when we advocate preparing our children for an envisioned computer future. There are millions and millions of digital devices and they annually draw on the nation's electricity. The count is higher every year and the rate of electricity consumption may be considerably underestimated.

A proportion of these are the computers in schools and they consume a significant percentage of our power. What matters is not just the utility bills. Millions of tons of carbon dioxide are generated and carbon dioxide contributes to atmospheric changes. Nitrogen oxides and sulfur oxides are emitted, too, and are the precursors of acid rain and acid soil.

Pat and I find these facts alarming. We feel anyone wanting to make today's children ready for the computer society should be asking serious questions:

- Have long term projections been made about the environmental impact of educational institutions' increased electricity use?

- What may the global future be like due to the side effects of pollution resulting from computerization?

- How will computerizing change lives and occupations in relation to the environmental consequences?

In summary, this committee needs to consider that it is expected each one of America's millions of students will use computers but there is little awareness of the likely ecological consequences. What should be the role of our school district?

\section{Principle}

\section{AECT Code of Professional Ethics Section 2 - Commitment to Society Principle 6}

In fulfilling obligations to society, the member:

6. Shall promote positive and minimize negative environmental impacts of educational technologies.

(Apply the principle to the scenario for yourself before going on to read the analysis.)

\section{Analysis}

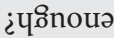

әиор әлеч nоК чәчм мочу nоК II!M

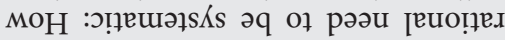

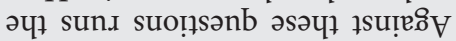

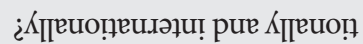

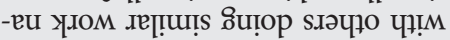

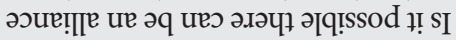

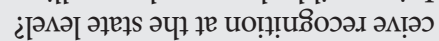

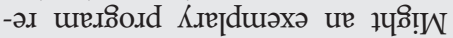

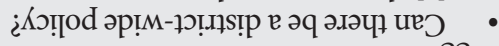

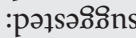

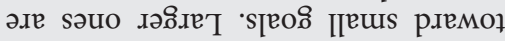

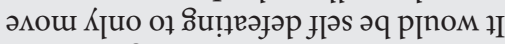

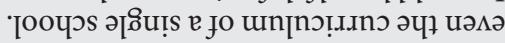

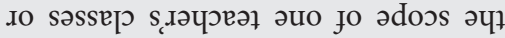

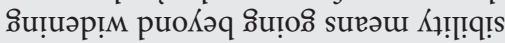

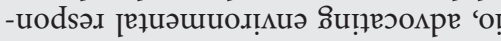

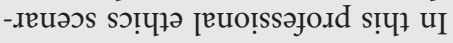
'TOOYวS

pue sə!!!

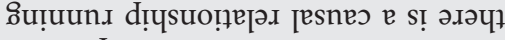

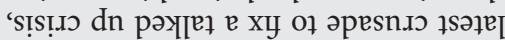

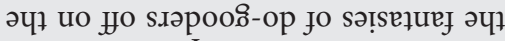

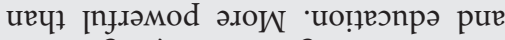

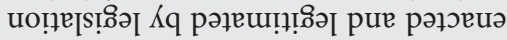

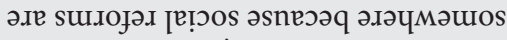

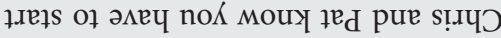

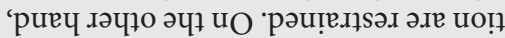

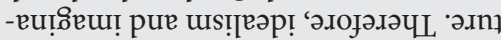

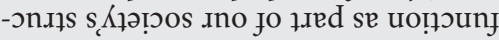

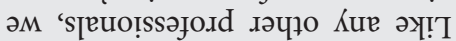

\section{About the Author}

Dr. Andrew R. J. Yeaman is the Professional Ethics Editor for TechTrends.

\section{Notes}

Professional ethics scenarios published in TechTrends are fictitious (see TechTrends, March-April, 2006, pp. 10-11). There is no intentional resemblance to specific people or particular organizations. The instructional purpose is to raise consciousness about AECT's Code of Professional Ethics. 